\title{
An Evaluation of the Performance of the Turkish Health System in the COVID-19 Pandemic
}

\author{
COVID-19 Pandemisinde Türk Sağlık Sisteminin Performansının Değerlendirilmesi
}

\author{
Hamza ATEŞ ${ }^{1}$ \\ (i) 0000-0003-0975-0062 \\ Harun KIRILMAZ ${ }^{2}$ \\ (D) 0000-0001-6055-6826
}

\begin{abstract}
${ }^{1}$ İstanbul Medeniyet University Faculty of Political Sciences Department of Political Science and Public Administration, İstanbul, Turkey

${ }^{2}$ Sakarya University Faculty of Management Department of Health Administration, Sakarya, Turkey
\end{abstract}

\section{Corresponding Author Sorumlu Yazar \\ Harun KIRILMAZ \\ hkirilmaz@sakarya.edu.tr}

Received / Geliş Tarihi : 08.01.2021 Accepted / Kabul Tarihi : 12.03.2021 Available Online /

Çevrimiçi Yayın Tarihi : 14.03.2021

\begin{abstract}
The coronavirus 2019 (COVID-19) pandemic is among the deadliest pandemics due to its impact on human health and its spread throughout the world. The impact of this outbreak has led to social, economic and human institutional transformations, especially health. Analyzing the performance of health systems at the point of identifying problems related to the current situation and developing solution suggestions, while providing opportunities to develop policy suggestions that will minimize the effects of the pandemic in the short term, can provide new perspectives to service delivery in the long term. This study aims to evaluate the performance of the Turkish health system in the COVID-19 pandemic and to contribute to the solution of problems. Within the scope of the study, the economic, social and technological effects of the COVID-19 pandemic were discussed, and its effects on the health system were evaluated. In the study, the performance of the health system and the reflections of the political and administrative system on the fight against the COVID-19 pandemic were also discussed. It is thought that this study will provide an opportunity to evaluate the effectiveness of the steps taken in combating the COVID-19 pandemic. As a result of the study, it will be possible to put forward a model proposal for the provision of health services in case of a global epidemic. In addition, in the COVID-19 pandemic, it is thought that the Ministry of Health will allow the evaluation of the health system and health service delivery.

Keywords: Health system; performance; pandemic.
\end{abstract}

\section{ÖZ}

Koronavirüs hastalığ 2019 (coronavirus disease 2019, COVID-19) pandemisi, insan sağlığ üzerindeki etkisi ve tüm dünya üzerindeki yayılımı itibariyle en ölümcül pandemiler arasında yer almıştır. Bu salgının yarattığı etki sağlık başta olmak üzere sosyal, ekonomik ve beşerî boyutta kurumsal dönüşümlere neden olmuştur. Mevcut duruma dair sorunların belirlenmesi ve çözüm önerilerinin geliştirilmesi noktasında, sağlık sistemlerinin performansını analiz etmek, k1sa vadede pandeminin etkilerini en aza indirecek olan politika önerilerinin geliştirilmesine fırsat tanırken, uzun vadede ise sağlık sektöründe hizmet sunumuna yeni perspektifler kazandırabilir. Bu çalışma, COVID-19 pandemisinde Türk sağlık sisteminin performansını değerlendirmeyi ve sorunlara çözüm noktasında katkıda bulunmayı hedeflemektedir. Çalışma kapsamında, COVID-19 salgınının ekonomik, sosyal ve teknolojik etkileri tartışılmış ve sağlık sistemi üzerindeki etkileri de değerlendirilmiştir. Ayrıca bu çalışmada, COVID-19 salgınıyla mücadelede sağlık sisteminin performansı ile siyasi ve yönetimsel sistemin yansımaları da tartışılmıştır. Bunun yanı sıra, bu çalışmanın COVID-19 pandemisiyle mücadelede atılan adımların etkinliği konusunda değerlendirme yapma imkânı da sağlayacağı düşünülmektedir. Çalışma sonucunda, küresel bir salgın durumunda sağlık hizmetlerinin sunumuna dair bir model önerisinin ortaya konulabilmesi mümkün olacaktır. Ayrıca, COVID-19 pandemisinde Sağlık Bakanlığı'nın sağlık sistemi ve sağlık hizmeti sunumunun değerlendirilmesine de imkan sağlanacağı düşünülmektedir.

Anahtar kelimeler: Sağlı sistemi; performans; pandemi. 


\section{INTRODUCTION}

It is predicted that the coronavirus disease 2019 (COVID-19) pandemic, which emerged in China at the end of 2019 and then spread rapidly all over the world, will intensely occupy the world agenda in 2020. In this process, the policies, strategies and plans of countries, international organizations and health authorities are carefully followed by the public. Undoubtedly, the effects of the COVID-19 pandemic are not limited to the field of health; it also brings about radical changes in almost every field, especially in politics, economy, finance, trade, energy, agriculture, tourism, education and management. It is possible to say that the COVID-19 pandemic is also the beginning of a period that breaks the routine in the system and policy perspective in the field of health, breaks the usual patterns and questions the prevailing health system in the world. As a matter of fact, the health system model, which connects access to health services to the conditions of the market mechanism and emphasizes the role of the state in preventive health services and health promotion, has failed in the COVID-19 pandemic. Developments in this process have resurfaced the role of the state in health services, citizens' access to health services and the importance of public health services.

COVID-19 emerged in December 2019 in the form of a pneumonia epidemic of unknown etiology in Wuhan City, Hubei province of China. A new type of coronavirus was identified as the causative agent of this disease and was later named COVID-19 by the World Health Organization (WHO). As a result of clinical studies, it has been revealed that COVID-19, which is considered a relative of severe acute respiratory syndrome (SARS) and Middle East respiratory syndrome (MERS), is caused by a betacoronavirus called SARS-CoV-2, which affects the lower respiratory tract and occurs as pneumonia in humans. (1). This virus is an enveloped RNA virus that causes severe respiratory failure and belongs to the coronavirus family such as SARS-CoV and MERS-CoV, identified by determining its transmission to human on January 7, 2020 (2).

There have been five pandemics caused by respiratory viruses in the world since the beginning of the twentieth century. The first four of these were caused by influenza (Influenza A) viruses, and the ongoing COVID-19 pandemic was caused by the coronavirus strain. The Spanish flu pandemic of 1918 covered nearly 500 million people worldwide and resulted in 40-100 million deaths, today considered the worst-case scenario for respiratory viral pandemics. In the COVID-19 pandemic, a new coronavirus disease with higher mortality is observed based on the type of virus and the age of the host, and a new page has been opened in the history of medicine. In addition to this, it is still an effective anti (corona) treatment of viral and in this case there are medical, sociological, psychological and macroeconomic consequences are felt around the world and in Turkey (3). The unlimited feature of globalization manifests itself in the negative effects of epidemic diseases that go beyond borders. Because these negative effects are not only the problem of the regions and administrations where epidemic diseases are experienced, but they become widespread globally in a short time; its cost is quite heavy, both economic and social (4).
First COVID-19 cases were seen in Turkey on March 9, 2020, while the first death occurred on March 17, 2020. Various preventive measures have been implemented in certain countries; including flight restrictions, gradual suspension of all flights and prevention of entry of foreign nationals, 14 days of isolation for arrivals from countries at risk, and symptom monitoring. In accordance with the pandemic plan, actions were taken with a multi-sectoral approach and preventive measures were taken to cover the society as a whole (5). In addition to international organizations such as WHO, UNESCO and UNICEF, local governments, Ministries of Health, disease control centers, health protection agencies, research centers and universities play crucial roles at different operational levels to control and survive the pandemic (6). In order to reduce the pandemic burden, attention is drawn to the issues of case definition, finding the cases and the first case set, appropriate treatment, adequate drug stocks and containment strategy and community cooperation (7).

The COVID-19 pandemic has revealed the necessity of configuring health systems to respond to a global epidemic around the world. Although restrictions and measures for the epidemic in China have reduced new cases by more than $90 \%$, this picture is not applicable in other countries. Many countries in Europe, especially Italy, have not been able to demonstrate a clear attitude and practice in restrictions and measures for the epidemic due to political, social and cultural dynamics. As a result of this picture, serious concerns have arisen about the capacity of the Italian healthcare system to effectively respond to the needs of infected COVID-19 patients who are infected and require intensive care. It is thought that the developments in Europe in the COVID-19 pandemic are closely related to the structure and functioning of the European Union, the socio-demographic structure, the structure and functioning of health systems (8).

\section{VARIOUS DIMENSIONS OF THE IMPACTS OF COVID-19 PANDEMIC}

COVID-19, which is declared by WHO as a pandemic, significantly affects Turkey as well as other countries in the World. Due to the current lack of a formal treatment plan and the uncertainty of the outbreak, the COVID-19 pandemic is expected to cause changes in many areas that are likely to be permanent in the long term. In other words, the short, medium and long term economic, social, human and so on. It is anticipated to cause effects. In this direction, after evaluating the economic, social and technological effects of the COVID-19 pandemic in general, its effects on the health system will be emphasized, and finally, the relationship between pandemic and health system performance will be discussed.

\section{Economic Impacts}

The COVID-19 pandemic is thought to have serious negative effects on employees, consumers, supply chains and financial markets, in short, it will cause a global economic recession. However, due to the uncertainty of the end of this pandemic, both the length and the scale of the global economic crisis that will emerge cannot be predicted (9). It is predicted that global trade will be reconstructed as a result of the serious economic losses caused by the 
COVID-19 pandemic, especially in China, Italy, France, Germany and the USA (10). Due to the COVID-19 pandemic, entry and exit bans to countries that many countries have implemented as a precaution, quarantines applied in areas where the epidemic was detected, international sports and arts events, congresses and travel restrictions that are in question have directly affected the tourism sector. It is thought that the COVID-19 pandemic will cause damages that can be felt in the economies of the country for a long time and the tourism sector will be directly adversely affected by these damages (11).

Using the SIR Model (S: Susceptible, I: Infectious, R: Recovered), which defines the dynamics of communicable diseases after the COVID-19 pandemic, the study reveals a projection on the economy over the next 12-18 months, to examine the negative effects of the COVID-19 pandemic on health and economy, attention is drawn to the difficulty of the steps to be taken to reduce it (12). The uncertainty of the course of the COVID-19 pandemic and its possible effects on the economy makes it difficult for policy makers to formulate an appropriate macroeconomic policy. It is predicted that the COVID-19 pandemic, which is expected to affect the global economy significantly in the short and medium term, will have more destructive effects, especially in underdeveloped economies and countries with high population density. Therefore, by investing more in preventive health services in these countries, the fight against global epidemics can be carried out with lower costs (13).

While the priority for health systems in the COVID-19 pandemic is to reduce disease-related deaths and prevent the spread of the disease, taking measures to ameliorate the economic recession is among the priorities of states. In this direction, it is emphasized that while hygiene and social isolation are the main things to be done in terms of health in the fight against the COVID-19 pandemic, where there is no official treatment plan, economic support packages are vital (14). Coordination should be established to control the pandemic, the flow of information should be regulated, the necessary health interventions (case management algorithms, vector control) should be determined, health systems (hospitals, healthcare personnel, medicine) should be strengthened, the society should be informed and the society should be included in pandemic surveillance and control (15).

\section{Social Impacts}

It has been observed that prioritizing preventive health services such as vaccines, hygiene and protective equipment in pandemics reduces the risk of contamination and spreading, while social capital dimensions contribute positively to individuals' intention to adopt and display health protective behaviors in pandemics. Similarly, it has been stated that individuals' trust in the state and health system increases the effectiveness of the fight against pandemics. In other words, developing interpersonal communication networks, taking steps to increase social capital, increasing the reliability of the state and the health system are the key points of an effective fight against the COVID-19 pandemic (16). According to Turkey in the public COVID-19 results of a study assessing the attitude towards the pandemic that has high sensitivity people against the pandemic, it was found to show maximum effort to protect and they have an average level of social trust (17).
Poor management, insufficient social cohesion and solidarity, insufficiency of vital equipment such as protective equipment, ventilator and intensive care bed, delayed managerial decisions are the biggest challenges in policy making in combating the COVID-19 pandemic. COVID-19 policies need to be addressed from a public health perspective, with intersectoral collaboration, with the global support of all countries, and a professional initiative (18). While different countries show different daily number of cases, total number of cases, and case mortality rates, it is seen that they show a similar epidemic curve. The international public and the scientific world are learning new data about the current epidemic every day. Since the outbreak is not yet over, every detail should be carefully evaluated and updates should be followed closely to monitor the epidemiological characteristics of COVID-19, in other words, the disease and risk factors and treatment methods (19).

Although there are advances in the treatment of COVID-19, it appears that there is currently no drug or treatment for this global pandemic that has a definite effect on the virus. COVID-19 is spreading strongly and effectively not only on public health but also on the economy, politics and social order. For this reason, hand hygiene, social distance and quarantine are the main points of preventing social spread in the fight against COVID-19. Undoubtedly, preventing social spreading is expected to have positive results not only in the field of health, but also in many areas such as economy, politics, management and social order (20).

As the COVID-19 pandemic affects disadvantaged groups more, the problem of inequality in access to healthcare has more devastating effects. In this framework, the issue should be handled in the perspective of social sciences and the health policies to be designed should identify and eliminate situations that lead to health inequalities, and health systems should ensure responsiveness (21). It is stated that the COVID-19 pandemic has caused serious pressure and crisis on the management, financing, service provision, medicine and medical device, healthcare personnel and health systems in information dimensions (22). Turkey and COVID-19 number of cases located in the top position in terms of overall positive number of cases in 22 countries, the number of patients who died in total, of the course of the epidemic by taking the assessment criteria the number of patients infected daily comparison and in a study that analyzes are carried out; it has been revealed that parameters such as population, area, air pollution level, number of healthcare personnel, number of hospital beds, obesity rate, happiness score, social support rate, average life expectancy are related to the performance of health systems of countries struggling with the COVID-19 pandemic (23).

\section{Technological Impacts}

It is seen that the COVID-19 pandemic brings along opportunities in many areas, especially in technology, on-line services and education, as well as its negative sociological, psychological and economic consequences, especially health. For example, based on the widespread digital learning experience that has been passed with a rapid adaptation due to the COVID-19 pandemic, it is predicted that this method will serve the development of this method all over the world, and in the near future, its 
functionality will increase and become the main learning structure with the contribution of new technologies and systems (24). Similarly, the COVID-19 pandemic has also provided an opportunity to use digital technologies more effectively in health. It is thought that the difficulties in providing healthcare services in disasters and epidemics can be overcome with the widespread use of digital technologies such as tele-medicine (25).

COVID-19 seriously threatens human health, production, life, social functioning and international relations. In the fight against COVID-19, Geographic Information Systems (GIS) and big data technologies have played an important role in many aspects, including the rapid collection of multi-source big data, rapid monitoring of epidemic information, and spatial tracking of confirmations. However, the main challenge to tackle the widespread epidemic is to adjust traditional technical methods and to find strategies to improve the speed and accuracy of information delivery for social management. At the data level, in the age of big data, data no longer mainly comes from the government, but is collected from more diverse businesses. As a result, the use of GIS faces difficulties in collecting data and integrating heterogeneous data that requires governments, businesses and academic institutions to jointly encourage the formulation of relevant policies. Today and for a long time in the future, the development of GIS should be strengthened to create a data-driven system for rapid information acquisition (26). Interaction models revealed in a study examining the role of social media platforms such as Twitter, YouTube, and Instagram in the COVID-19 pandemic show that when combined with the characteristics of each social media platform's audience, it plays an important role in the spread of information and misinformation (27). The lack of evidence-based data on COVID-19, which has been declared a global epidemic, and the disinformation emerging on social media make the rapid and objective management of the process difficult. Within this framework, with the widespread use of accredited studies, it will be possible to manage and plan this global epidemic more effectively, to clarify the current situation and to make clearer projections for the future (28).

\section{Impacts on the Health System}

The COVID-19 pandemic has shown that health systems need additional financial resources at national and regional levels to combat global epidemics. On the other hand, it is important to supply infrastructure and medical supplies such as protective equipment, diagnostic kits, ventilator and intensive care bed, as well as the need for adequate health personnel in terms of quantity and quality. It is also critical for individuals to adapt to extraordinary living conditions such as quarantine and social isolation for a long time during the epidemic process. It seems that coordination and harmony between central and local governments are among the success factors in combating global epidemics. Finally, it is expected that the picture that will emerge after the epidemic will cause the need for additional investment in the health sector (29).

By using data from 182 countries to compare health systems in the context of the COVID-19 pandemic, Kandel et al. (30) made a comparison. According to the results of the study, 52 of 182 countries have 1 or 2 level prevention capacity, 60 of them have 1 or 2 level response capacity. It turns out that 81 countries have 4 or 5 level prevention capacity, 78 countries have 4 or 5 level response capacity. 138 countries scored higher in detection dimension than other dimensions. 44 countries did not have an effective activation function for public health risks and events, including epidemics, and 102 countries were found to have 4 or 5 level activation capacity. While 32 countries have low operational capacity, 104 countries have a high level of operational capacity to prevent, detect and control an outbreak. According to the results obtained from the study, countries differ greatly in their capacity to prevent, detect and respond to outbreaks. It is noted that while half of the countries analyzed have strong operational readiness capacities, the findings from local risk assessments are needed to fully understand national preparedness capacities for COVID-19. In other words, capacity building and cooperation between countries is required for global epidemic control (30).

In the studies of Legido-Quigley et al. (29), based on the recent pandemics such as $\mathrm{H} 5 \mathrm{~N} 1$ and $\mathrm{H} 1 \mathrm{~N} 1$, based on the examples of Hong Kong, Singapore and Japan, they examined whether high-performance health systems give a more successful test in the COVID-19 pandemic; they drew attention to the importance of integration into the health system and other sectors to combat the epidemic, the spread of fake news and false information is a major challenge, and the trust of patients, healthcare professionals and the public in the state is of great importance in overcoming crises. According to the results of this study, 9 dimensions stand out in the high performance of a health system in a pandemic such as COVID-19: 1) Detection and isolation, 2) Coordination with other countries, 3) Patients' treatment being covered by social security, 4) Routine health services (coordination between hospitals, local governments and private sector, intensive care bed capacity), 5) Medicines and personal protective equipment used in the treatment of COVID-19 (masks, overalls, visors, etc.), 6) Infection prevention and control activities in hospitals, 7) Health information system and information sharing, 8) Risk communication, 9) Anxiety management (29). In other words, it is possible to say that a health system must have sufficient capacity in these dimensions in order to exhibit high performance in a pandemic such as COVID-19.

\section{PANDEMIC AND HEALTH SYSTEM PERFORMANCE}

Considering the studies emphasizing the relationship between the performance of health systems and the effectiveness of combating pandemics in the literature $(8,16-18,21-23,29,30)$, it is considered important to investigate the relationship between performance levels of health systems and health service delivery and health outcomes in the COVID-19 pandemic. The performance approach, which came to the agenda for the first time in the healthcare sector with the World Health Report published by WHO in 2000 (31), revealed the goals of strengthening health systems and improving human health with the Tallinn Convention, which was signed and accepted by the member countries of the WHO European Region in 2008 (32). Again, in the 2009 European Health Report published by WHO, it was emphasized that improving the performance of the health system should be 
a priority target (33). OECD Health System published in 2008 Studies: The report called Turkey, according to WHO's approach to health care in the performance of the equity and financial risk protection reveal their goals. In the said report, it was stated that the Turkish health system had a high performance in terms of absolute conditions and in terms of equity and financial risk protection when compared to other countries (34).

In this direction, it formed the basis of the understanding of performance management in health services that emerged in the USA and Europe at the end of the $20^{\text {th }}$ century, and health reforms in many countries in a short time. The institutional structure and service delivery in the health sector has increasingly focused on the understanding of performance $(35,36)$. The world according to these developments in Turkey, which was introduced in 2003 by the Ministry of Health, Health Transformation Program, it is possible to say that laid the foundations of performance management approach. With the Health Transformation Program, which aims to act in accordance with the principles of efficiency, productivity and equity in the organization, financing and delivery of health services, it is aimed to increase the health level of the society (37). Efficiency, quality service provision and access to health services are considered as important tools to achieve high performance in healthcare services, and these tools are the elements that constitute the objectives of the Health Transformation Program. As a matter of fact, the objectives of the Health Transformation Program are to organize, finance and provide health services in an effective, efficient and equitable manner (38).

\section{PANDEMICS AND POLITICAL/ADMINISTRATIVE SYSTEM}

The political and administrative process which Turkey has followed in its fight with the COVID-19 pandemic has been carried out within the framework of a model which is based on coordination and governance principles. The COVID-19 pandemic has revealed, once again, the importance of state capacity, trust and good governance, as well as effectiveness of the health system and strength of health infrastructure as effective factors in combating crises. Another lesson the COVID-19 pandemic has taught us that governments need to have a solid and good working public administration structure in order to quickly cope with the crises and produce widespread and effective responses to the crised they have encoured whatever the nature and extent of the crisis may be. In this context, another complementary parameter of social policy elements such as public health, basic services and economic protection policies is the prominence of the security/public order perspective. The healthy and transparent operation of public communication is considered as another important reason for success in combating the COVID-19 pandemic. Informing the public regularly and transparently prevents the increase of vulnerability at the social level and instills trust in the society and ensures that it survives financially, socially and mentally. On the other hand, the importance of the national capacity of countries, especially in the fields of economy, technology and health, has been evident in the COVID-19 pandemic, where the borders between countries are closed and nations are left on their own (39).
It is also seen within the framework of COVID-19 pandemic that the political and administrative structure and functioning of the Turkish health system as well as the structure and functioning of the Turkish healthcare system are decisive on the process and outcome. Indeed, in 2017 the Constitutional Referendum and the political system changed in Turkey after the 2018 elections; a presidential system, in which the President uses the executive power defined in the Constitution, has been introduced. Significant changes in the role, functioning and organizational model of the Ministry of Health in the Presidential Government System have come to the fore (40). It has been observed that the Presidential Government System can give early, fast and decisive responses to such crises as the COVID-19 pandemic, unlike the parliamentary system, with its rapid and determined policy-making process (41).

In this process, the recommendations and decisions of the Scientific Committee established within the Ministry of Health were implemented without delay. At the same time, it has been observed that all ministries, especially the Ministry of Health, and other official institutions act jointly. The harmonization of state institutions has accelerated and facilitated the taking of measures. Turkey is unprecedented in the process of propagation of the epidemic in point Ministry to take measures in matters within their areas of interest and negative statements in coordination with other Ministries execution. From this point of view, it is evaluated that the Presidential Government System passed a successful test in the COVID-19 pandemic (42).

As it is quite well-known, Turkey and Iran exhibit many similarities in terms of population, and a number of other human development criteria. In a comparative study of these two counties in terms of their performance at fight against COVID-19 pandemic, a number of interesting results have been revealed. According to the abovementioned comparative study, number of the cases and speed of the infection spread are similar in both countries, but the death toll in Turkey is much lower, when compared with Iran.

The prime reason for the relative success of Turkish government in its fight with COVID-19 pandemic would be the fact that the Presidential Government System allows the health bureaucracy and other institutions to act in a coordinated manner. Some other factors impacting on this result include economic differences between Turkey and Iran, relatively strong financial position of Turkey and the fact that Turkey has had more health resources such as intensive care unit, medical equipment and test kits (43). Another study evaluating Turkey's strategies against COVID-19 pandemic has revealed that, the reasons for this success can be attributed to measures taken in order to maintain social distance among citizens, travel ban on visitors from high risk countries; quarantine measures for citizens returning from such countries; and the implementation of various restrictions such as the closure of educational institutions, shopping centers and entertainment venues. Having a young population of Turkey is ready adequacy of health personnel and health facility also has the capacity to provide a significant advantage in this context. According to the results of the research mentioned above, the regular sharing of current 
data and information on the subject with the communication and information network of the Ministry of Health contributes to the awareness of the citizens and creates trust (44). In other words, domestic and international travel restrictions, curfews, quarantine, tourism and accommodation facilities, restrictions on wedding, engagement ceremonies, funeral organizations that allow citizens to be found together, closure of workplaces and flexible working arrangements, law enforcement and inspection and controls, etc. The administrative measures taken enabled the COVID-19 pandemic to be kept under control (45).

In another study examining the role and function of central and local governments in the COVID-19 pandemic based on various countries, central governments' travel restrictions, increasing the capacity of health services, without applying financial and economic measure packages, banning the use of schools and various meeting areas, mandatory quarantine practices. It has been observed that it has carried out many activities, ranging from informing citizens about combating the virus.

It has been observed that the services that local governments try to provide to citizens within the scope of combating the COVID-19 pandemic are mostly services for local people (for example, public transportation, food and accommodation support, regulation of urban traffic and information activities). Therefore, extraordinary periods such as the COVID-19 pandemic have shown the necessity of central government and local governments to provide services to citizens in cooperation and coordination. Combining the points where central government and local governments are advantageous in service provision and cooperating by establishing coordination between them will provide faster, effective, efficient and fair service to citizens (46).

\section{CONCLUSION}

At the point of analyzing the social, human and economic effects of the COVID-19 pandemic, especially on health, determining the problems and developing solutions; it is important to reveal the relationship between the performance of the health system and health service delivery and outcomes in global epidemics. With the Health Transformation Program accessibility of Turkey's health system, satisfaction, service delivery, the high performance demonstrated in many aspects, especially hedge, and it seems so it provides significant improvement in health indicators (47).

In other words, detection and isolation, coordination with other countries, treatment of patients under social security, provision of routine health services (coordination between hospitals, local governments and the private sector, intensive care bed capacity), drugs and personal protective equipment used in the treatment of COVID-19 (it is expected to contribute to the evaluation of the perceptions of citizens and healthcare professionals about the performance of the Turkish health system in terms of masks, overalls, visors, etc.), infection prevention and control activities in hospitals, health information system and information sharing, risk communication and anxiety management.

The COVID-19 pandemic, which has affected the whole world, has brought significant changes in almost every field, especially in the health system. The process of change has negative aspects as well as some positive aspects. For example, changes that will occur in the field of digitalization in the long term have entered our lives extremely quickly in the COVID-19 pandemic. Undoubtedly, in the COVID-19 pandemic, especially health systems, economy, education, technology, management, etc. It is important to identify problem areas in many areas and to implement effective and fast solutions. At this point, it is imperative that health systems show a high performance in combating a global epidemic such as the COVID-19 pandemic.

The COVID-19 pandemic has brought about radical changes in almost every field such as healthcare, economy, politics, management, technology, and education. Undoubtedly, this process has revealed the necessity of structuring health systems in a way that can respond to a global epidemic. Developments in this process have reaffirmed the role of the state in health services, access to health services and the importance of public health services. However, the fight against the COVID-19 pandemic is so multidimensional and complex that it cannot be addressed solely from the perspective of the healthcare system and healthcare services.

In combating the COVID-19 pandemic, it is beneficial to consider the political and administrative process from a coordination and governance perspective. Undoubtedly, the political and administrative system is a determining factor in combating the COVID-19 pandemic. At this point, the process of determining the swift and decisive policy of presidential government system in Turkey is thought to contribute to the success of that struggle. On the other hand, it has been observed that cooperation and coordination between central government and local governments are also important in this process.

Ethics Committee Approval: Since our study was a review, ethics committee approval was not required.

Conflict of Interest: None declared by the authors.

Financial Disclosure: None declared by the authors.

Acknowledgements: None declared by the authors.

Author Contributions: Idea/Concept: HA; Design: HA, HK; Data Collection/Processing: HK; Analysis/Interpretation: HA, HK; Literature Review: HA, HK; Drafting/Writing: HK; Critical Review: HA.

\section{REFERENCES}

1. Sohrabi C, Alsafi Z, O'Neill N, Khan M, Kerwan A, Al-Jabir A, et al. World Health Organization declares global emergency: A review of the 2019 novel coronavirus (COVID-19). Int JSurg. 2020;76:71-6.

2. Türkiye Bilimler Akademisi. COVID-19 pandemi değerlendirme raporu (No:34). Ankara: TÜBA; 2020.

3. Temel MK, Ertin H. Lessons from the 1918 influenza pandemic for the COVID-19 pandemic. Anatol Clin. 2020;25(Special Issue on COVID 19):63-78.

4. Çınarlı İ. SARS (severe acute respiratory syndrome) outbreak regarding risk communication. İleti-ş-im. 2005;2:55-69. 
5. Demirbilek Y, Pehlivantürk G, Özgüler ZÖ, Alp Meşe E. COVID-19 outbreak control, example of ministry of health of Turkey. Turk J Med Sci. 2020;50(SI-1):48994.

6. Koçak Tufan Z, Kayaaslan B. Crushing the curve, the role of national and international institutions and policy makers in COVID-19 pandemic. Turk J Med Sci. 2020;50(SI-1):495-508.

7. Akın L, Gözel MG. Understanding dynamics of pandemics. Turk J Med Sci. 2020;50(SI-1):515-9.

8. Remuzzi A, Remuzzi G. COVID-19 and Italy: what next? Lancet. 2020;395(10231):1225-8.

9. Açıkgöz Ö, Günay A. The early impact of the COVID19 pandemic on the global and Turkish economy. Turk J Med Sci. 2020;50(SI-1):520-6.

10. Zeren F, Hizarc1 AE. The impact of COVID-19 coronavirus on stock markets: evidence from selected countries. Bulletin of Accounting and Finance Reviews. 2020;3(1):78-84.

11. Acar Y. The novel coronavirus (COVID-19) outbreak and impact on tourism activities. Güncel Turizm Araştırmaları Dergisi. 2020;4(1):7-21.

12. Atkeson A. What will be the economic impact of COVID-19 in the US? Rough estimates of disease scenarios. NBER Working Papers. 2020;26867. doi: 10.3386/w26867.

13. McKibbin W, Fernando R. The global macroeconomic impacts of COVID-19: Seven scenarios. CAMA Working Paper Series. 2020;19. Available from: https://cama.crawford.anu.edu.au/publication/camaworking-paper-series/16221/global-macroeconomicimpacts-covid-19-seven-scenarios.

14. Anderson RM, Heesterbeek H, Klinkenberg D, Hollingsworth TD. How will country-based mitigation measures influence the course of the COVID-19 epidemic? Lancet. 2020;395(10228):931-4.

15. Çetin C, Kara A. Global surveillance, travel, and trade during a pandemic. Turk J Med Sci. 2020;50(SI1):527-33.

16. Chuang YC, Huang YL, Tseng KC, Yen CH, Yang LH. Social capital and health-protective behavior intentions in an influenza pandemic. PLoS One. 2015;10(4):e0122970.

17. Bostan S, Erdem R, Öztürk YE, Kılıç T, Yılmaz A. The effect of COVID-19 pandemic on the Turkish society. Electron J Gen Med. 2020:17(6):em237.

18. Raoofi A, Takian A, Akbari Sari A, Olyaeemanesh A, Haghighi H, Aarabi M. COVID-19 pandemic and comparative health policy learning in Iran. Arch Iran Med. 2020;23(4):220-34.

19. Bulut C, Kato Y. Epidemiology of COVID-19. Turk J Med Sci. 2020;50(SI-1):563-70.

20. Güner R, Hasanoğlu İ, Aktaş F. COVID-19: Prevention and control measures in community. Turk $\mathbf{J}$ Med Sci. 2020;50(SI-1):571-7.

21. Wang Z, Tang K. Combating COVID-19: health equity matters. Nat Med. 2020;26(4):458.

22. Legido-Quigley H, Mateos-García JT, Campos VR, Gea-Sánchez M, Muntaner C, McKee M. The resilience of the Spanish health system against the COVID-19 pandemic. Lancet Public Health. 2020;5(5):e251-2.

23. Ergül B, Altın Yavuz A, Gündoğan Aşık E, Kalay B. Statistical evaluation of the COVID-19 outbreak data as of april around the World and in Turkey. Anatol Clin. 2020;25(Special Issue on COVID 19):130-41.

24. Telli Yamamoto SG, Altun D. The coronavirus and the rising of online education. Journal of University Research. 2020;3(1):25-34.

25. Hollander JE, Carr BG. Virtually perfect? Telemedicine for COVID-19. N Engl J Med. 2020;382(18):1679-81.

26. Zhou C, Su F, Pei T, Zhang A, Du Y, Luo B, et al. COVID-19: Challenges to GIS with big data. Geography and Sustainability. 2020;1(1):77-87.

27. Cinelli M, Quattrociocchi W, Galeazzi A, Valensise CM, Brugnoli E, Schmidt AL, et al. The COVID-19 social media infodemic. Sci Rep. 2020;10(1):16598.

28. Kakodkar P, Kaka N, Baig MN. A comprehensive literature review on the clinical presentation, and management of the pandemic coronavirus disease 2019 (COVID-19). Cureus. 2020;12(4):e7560.

29. Legido-Quigley H, Asgari N, Teo YY, Leung GM, Oshitani H, Fukuda K, et al. Are high-performing health systems resilient against the COVID-19 epidemic? Lancet. 2020;395(10227):848-50.

30. Kandel N, Chungong S, Omaar A, Xing J. Health security capacities in the context of COVID-19 outbreak: An analysis of International Health Regulations annual report data from 182 countries. Lancet. 2020;395(10229):1047-53.

31. World Health Organization. The World Health Report 2000, health systems: Improving performance. Geneva: World Health Organization; 2000.

32. World Health Organization. The Tallin Charter: Health systems for health and wealth. Copenhagen: World Health Organization; 2008.

33. World Health Organization. The European health report 2009, health and health systems. Copenhagen: World Health Organization; 2009.

34. The Organization for Economic Co-operation and Development. OECD reviews of health systems: Turkey 2008. Paris: OECD; 2008.

35. Handler A, Issel M, Turnock B. A conceptual framework to measure performance of the public health system. Am J Public Health. 2001;91(8):1235-9.

36. Özcan YA. Health care benchmarking and performance evaluation. New York: Springer; 2008.

37. Sağlık Bakanlığı. Sağlıkta dönüşüm. Ankara: Sağlık Bakanlığı; 2003.

38. Ateş H, Kırılmaz H, Aydın S. Sağlık sektöründe performans yönetimi: Türkiye örneği. Ankara: Asil Yayınları; 2007.

39. Babacan A. Post-COVID-19 period and new institutional politics in Turkey. In: Şeker M, Özer A, Korkut C, editors. Reflections on the pandemic: In the future of the World. Ankara: TÜBA; 2020. p.393-423.

40. Kırılmaz H. Yönetim ve sağlık yönetimi. In: Özer MA, editor. Yönetim ve: Yönetim'e disiplinleraras1 yaklaşım. Ankara: Gazi Kitabevi; 2019. p.437-78.

41. Bakır C. The Turkish state's responses to existential COVID-19 crisis. Policy Soc. 2020;39(3):424-41.

42. Erdem İ. Quarantine and precaution policies of Turkey against coronavirus (COVID-19). Turkish Studies. 2020;15(4):377-88.

43. San S, Bastug MF, Basli H. Crisis management in authoritarian regimes: A comparative study of 
COVID-19 responses in Turkey and Iran. Glob Public Health. 2020; [Epub ahead of print]. doi: 10.1080/17441692.2020.1867880.

44. Çınar F, Oğuz M. Evaluation of Turkey's COVID-19 SWOT analysis of strategy for pandemic. Sağlık ve Sosyal Refah Araştırmaları Dergisi. 2020;2(2):1-11.

45. Artantaş E, Gürsoy H. Basic social discussions on COVID-19 and a framework own taken to measures
Turkey's. Niğde Ömer Halisdemir Üniversitesi Sosyal Bilimler Enstitüsü Dergisi. 2020;2(2):158-71.

46. Bilgili MY. Central government, local governments and coronavirus (COVID-19) pandemic. Turkish Studies. 2020;15(6):219-35.

47. Republic of Turkey Ministry of Health. Health statistics yearbook 2018. Ankara: Ministry of Health Publication; 2019. 